eCo-Buss

\title{
Pengaruh Kualitas Produk dan Harga Terhadap Minat Beli Konsumen Smartphone Bergaransi Distributor Pada PT. Tiga Agung
}

\author{
Adrian Hidayat ${ }^{1)}$ \\ Gustin Hartanto $^{2)}$ \\ Universitas Buddhi Dharma \\ ahnangka67@yahoo.com
}

\begin{abstract}
Abstrak
Tujuan Penulisan Penelitian Ini Adalah Untuk Mengetahui Sejauh Mana Pengaruh Kualitas Produk Dan Harga Terhadap Minat Beli Konsumen Smartphone Bergaransi Distributor Pada PT. Tiga Agung (Studi Kasus Konsumen Mahasiswa Universitas Buddhi Dharma). Penelitian Yang Dilakukan Adalah Dengan Menyebarkan Kuesioner, Sedangkan Untuk Metode Penelitian Yang Dilakukan Adalah Dengan Menggunakan Metode Deskriptif. Dalam Melakukan Penelitian Ini Penulis Menggunakan Analisis Koefisien Korelasi, Analisa Regresi Linier Berganda Dan Uji F Serta Uji T. Menggunakan Analisis Linear Berganda, Analisis Koefisien Korelasi, Menghitung Koefisien Determinasi Serta Melakukan Uji Hipotesis Dengan Mencari Nilai F Hitung Kemudian Membandingkan F Hitung Dengan F Table. Hasil Analisa Regresi Linear Berganda Di Peroleh Persamaan Y $=14.458+0.405 \mathrm{X}_{1}+0.258 \mathrm{X}_{2}$ Artinya Setiap Perubahan Sebesar 1 Point Maka X1 (Kualitas Produk) Mengalami Peningkatan Atau Penurunan Sebesar 0.405, Setiap Perubahan Sebesar 1 Point Maka X2 (Harga) Mengalami Peningkatan Atau Penurunan Sebesar 0.258. Berdasarkan Hasil Uji Hipotesis Di Peroleh $F_{\text {hitung }}$ Model 1 Sebesar 53.780 , $F_{\text {hitung }}$ Model 2 Sebesar 31.828 , Dimana Nilai Tersebut Lebih Besar Dari $F_{\text {tabel }}$ Sebesar 3,16 . Dengan Demikian Ho Di Tolak Dan Ha Di Terima. Artinya Terdapat Hubungan Antara Kualitas Produk Dan Harga Terhadap Minat Beli Konsumen
\end{abstract}

\section{Kata Kunci : Kualitas Produk, Harga Dan Minat Beli}

\section{Pendahuluan}

Jumlah Penduduk Indonesia Yang Sangat Besar Menjadi Pasar Yang Sangat Potensial Bagi Perusahaan-Perusahaan Untuk Memasarkan Produk-Produk Perusahaan Tersebut. Perusahaan Dalam Negeri Maupun Perusahaan Asing Berusaha Mendirikan Usaha Bisnis Dan Menciptakan Jenis-Jenis Produk Yang Nantinya Akan Digemari Oleh Calon Pelanggannya. Banyaknya Perusahaan Ini Menciptakan Adanya Suatu Persaingan Bisnis, Perusahaan Dapat Menjadi Pemenang Dalam Persaingan Bisnisya Apabila Perusahaan Tersebut Berhasil Menjaring Pelanggan Sebanyak-Banyaknya. Jika Perusahaan Dapat Menjaring Pelanggan Yang Banyak Tentu Perusahaan Tersebut Dapat Memperoleh Keuntungan Yang Besar Juga. Dinamika Dalam Dunia Usaha Yang Semakin Menantang, Membuat Para Perusahaan Harus Dapat Menjawab Tantangan Pasar Dan Memanfaatkan Tantangan Tersebut Sebagai Peluang Untuk Dapat Bertahan Dimasa Yang Akan Datang. (Buchari, 2011) Ketatnya Persaingan Dalam Dunia Usaha Menuntut Setiap Perusahaan Untuk Mengambil Langkah-Langkah Serta Strategi Yang Jitu Guna Memenangkan Persaingan Dengan Kompetitor Demi Menjaga Eksistensi Yang Dimiliki Dan Tentunya Mempertahankan Bahkan Meningkatkan Keuntungan Atau Profit Yang Dihasilkan. Tanpa Strategi Yang Jitu Perusahaan Tidak Akan Dapat Bertahan Karena Seiring Waktu Kompetitor Akan Terus 
Muncul Bersamaan Dengan Permintaan Konsumen Yang Kian Meningkat. Hal Ini Dihadapi Oleh Setiap Perusahaan Yang Mencari Laba Dan Tidak Terkecuali Industri Elektronik.

Saat Ini, Perkembangan Jumlah Penduduk Yang Cukup Pesat Serta Beragamnya Aktivitas Kerja Setiap Orang Memungkinkan Segala Aktivitas Tersebut Harus Dilakukan Secara Cepat. Agar Orang Dapat Melakukan Pekerjaan Secara Cepat, Dibutuhkan Sarana Pendukung, Seperti Alat Telekomunikasi Atau Smartphone. Kebutuhan Akan Alat Telekomunikasi Dewasa Ini Telah Menjadi Kebutuhan Primer. Selain Berfungsi Untuk Melakukan Dan Menerima Panggilan Telepon, Smartphone Umumnya Juga Mempunyai Fungsi Pengiriman Dan Penerimaan Pesan Singkat Atau Disebut Sms. Ada Pula Penyedia Jasa Smartphone Di Beberapa Negara Yang Menyediakan Layanan Generasi Ketiga Atau 3G Dengan Menambahkan Jasa Video Phone, Sebagai Alat Pembayaran, Maupun Untuk Televisi Online Di Smartphone Mereka. Sekarang Smartphone Menjadi Gadget Yang Multifungsi. Mengikuti Perkembangan Teknologi Digital, Kini Smartphone Juga Dilengkapi Dengan Berbagai Pilihan Fitur, Seperti Bisa Menangkap Siaran Radio Dan Televisi, Perangkat Lunak Pemutar Audio Dan Video, Kamera Digital, Game, Dan Layanan Internet. (Bachriansyah, 2011) Selain Fitur-Fitur Tersebut, Smartphone Sekarang Sudah Ditanamkan Fitur Komputer, Jadi Dismartphone Tersebut Orang-Orang Bisa Mengubah Fungsi Dari Smartphone Tersebut Menjadi Mini Komputer. Di Dalam Dunia Bisnis, Fitur Ini Akan Sangat Membantu Bagi Para Pebisnis Untuk Melakukan Semua Pekerjaannya Di Satu Tempat Dan Membuat Pekerjaannya Tersebut Diselesaikan Dalam Waktu Yang Singkat. Dengan Semakin Banyak Orang-Orang Yang Menggunakan Smartphone Maka Produksi Massal Akan Bisa Dilakukan Harga Smartphone Di Seluruh Dunia Cenderung Semakin Murah Dari Tahun Ke Tahun. Jika Dahulu Smartphone Merupakan Sebuah Barang Yang Langka Dan Eksklusif Atau Hanya Untuk Orang Yang Mampu, Kalangan Atas, Maka Saat Ini Hampir Semua Lapisan Masyarakat Sudah Bisa Memiliki Dan Menikmati Kenyamanan Berkomunikasi Menggunakan Smartphone.

(Yasa \& Prawira, 2014) Kualitas Merupakan Hal Yang Terpenting Dalam Suatu Barang, Bisa Dilihat Di Jaman Sekarang Orang-Orang Pasti Yang Akan Membeli Suatu Produk Elektronik Biasanya Akan Menanyakan Perihal Tentang Kualitas Produk Tersebut. (Annafik \& Rahardjo, 2012) Dalam Hal Kualitas Produk, Kualitas Yang Ada Pada Smartphone Bergaransi Distributor Sama Bagusnya Dengan Yang Bergaransi Resmi, Itu Karena Barang Yang Didatangkan Berasal Dari Vendor Atau Perusahaan Yang Sama, Sehingga Kualitasnya Pun Sama.

Faktor Harga Disini Juga Tidak Kalah Penting, Harga Juga Merupakan Salah Satu Faktor Yang Menetukan Dalam Mengambil Keputusan Untuk Membeli (Andy, 2018). Harga Yang Ditawarkan Oleh Garansi Distributor Terbilang Cukup Lebih Murah Dibanding Dengan Garanci Resmi, Ini Bertujuan Untuk Menarik Minat Para Konsumen.

Adapun Tujuan Dari Penelitian Ini Adalah Sebagai Berikut: Untuk Mengetahui Kualitas Produk Yang Dimiliki Akan Memberikan Pengaruh Terhadap Minat Beli Konsumen, Dan Mengetahui Harga Yang Telah Terbentuk Oleh PT. Tiga Agung

\section{Metode Penelitian}

Metode Penelitian Ini Merupakan Suatu Sistem Atau Cara Bekerja Dibidang Yang Bersifat Sistematis Yng Bertujuan Untuk Mendapatkan Hasil Yang Memadai Dalam Penelitian Yang Bersifat Ilmiah. Dalam Penelitian Ini Penulis Menggunakan Beberapa 
Metode Penelitian Yang Merupakan Salah Satu Cara Untuk Mengumpulkan Data Dan Informasi Secara Objektif Dan Relevan Sehingga Memudahkan Peyusunan.

Metode Penelitian Yang Digunakan Penulis Adalah Metode Deskriptif Adalah Suatu Metode Dalam Meneliti Status Kelompok Manusia, Suatu Objek, Suatu Set Kondisi, Suatu Sistem Pemikiran, Ataupun Suatu Kelas, Peristiwa Pada Masa Sekarang. Tujuan Dari Penelitian Deskriptif Ini Adalah Untuk Membuat Penelitian, Gambaran Atau Lukisan Secara Sistematis, Faktual Dan Akurat Mengenai Fakta-Fakta, Sifat-Sifat Serta Hubungan Antar Fenomena Yang Diselidiki.

\section{Teknik Pengumpulan Data}

Teknik Pengumpulan Data Merupakan Langkah Yang Paling Strategis Dalam Penelitian Karenatujuan Dari Penelitian Adalah Mendapatkan Data. Tanpa Mengetahui Teknik Pengumpulan Data, Maka Peneliti Tidak Akan Mendapatkan Data Yang Memenuhi Standar Data Yang Ditetapkan.

Dalam Usaha Untuk Mengumpulkan Data Yang Akurat Dan Valid, Maka Penulis Mengumpulkan Data Dan Informasi Dari Berbagi Sumber Dengan Cara :

Riset Lapangan (Field Researc)

Merupakan Metode Paengumpulan Data Dengan Cara Meninjau Langsung Ke Universitas Yang Dalam Penelitian Ini Adalah Universitas Buddhi Dharma Selaku Objek Penelitian, Penelitian Ini Dilakukan Untuk Mengumpulkan Data Primer, Dengan :

a. Wawancara (Interview)

Yaitu Dengan Cara Mengadakan Tanya Jawab Secara Langsung Kepada Mahasiswa UBD Yang Melakukan Pemakaian Dan Pembelian Smartphone.

b. Angket (Kuesioner)

Angket (Kuesioner) Merupakan Pengumpulan Data Dengan Memberikan Atau Menyerahkan Daftar Pertanyaan Atau Pernyataan Kepada Responden Dengan Harapan Memberikan Respos Atas Daftar Pertanyan Atau Pernyataan Tersebut. Daftar Pertanyaan Atau Pernyataan Dapat Bersifat Terbuka Jika Jawaban Tidak Di Tentukan Sebelumnya, Sedangkan Bersifat Tertutup Jika Alternative-Alternative Jawaban Telah Di Siapkan. Instrumen Yang Berupa Daftar Pertanyya Atau Pernyataan Tadi Berupa Angket (Kuesioner), Checklist Ataupun Skala. Dalam Hal Ini Peneliti Menyebarkan Kuesioner Kepada Responden Langsung Yang Menggunakan Dan Membeli Smartphone. Penulis Mengumpulkan Data Dengan Cara Menyebarkan Kuesioner Sebanyak Seratus Lembar.

c. Pengamatan (Observasi)

Mengumpulkan Data Dengan Cara Melakukan Pengamatan Langsung Kepada Konsumen. Ini Dilakukan Dengan Tujuan Untuk Membandingkan Secara Silang Antara Hasil Survey Dengan Kenyataan Yang Ada Guna Memperkuat Hasil Wawancara Kuesioner.

\section{Metode Penarikan Sampel}

(Sugiyono, 2010) Dalam Penelitian Ini, Responden Ditentukan Berdasarkan Sampel Sebuah Populasi Dan Sampel Merupakan Bagan Dari Populasi. Dimana Populasi Adalah Suatu Kumpulan Menyeluruh Daru Suatu Objek Yang Merupakan Perhatian Peneliti. Objek Penelitian Dapat Berupa Mahluk Hidup, Benda, System, Prosedur, Fenomena, Dan LainLainnya. 
Beberapa Unsur Dalam Menentukan Sampel, Yakni Sebagai Berikut :

a. Populasi Adalah Wilayah Generalisasi Yang Terdiri Atas Objek Atau Sabjek Yang Mempunyai Kualitas Dan Karakteristik Tertentu Yang Ditetapkan Oleh Peneliti Untuk Dipelajari Dan Kemudian Ditarik Kesimpulanya. Populasi Yang Dimaksud Adalah Mahasiswa UBD Yang Memakai Smartphone.

b. Sampel Adalah Bagian Dari Jumlah Dan Karakteristik Yang Dimiliki Oleh Populasi Tersebut. Besarnya Populasi Dalam Penelitian Yang Akan Dilakukan, Dan Dalam Waktu Terbatas Yang Dimiliki Oleh Peneliti, Maka Sampel Yang Diambil Adalah Sebanyak 60 Responden Dengan Menyebarkan 100 Kuesioner. Sampel Diambil Secara Pilihan (Probability Sampling), Yaitu Teknik Yang Tidak Memberikan Peluang Atau Kesempatan Sama Bagi Setiap Unsur Atau Anggota Populasi Untuk Dipilih Menjadi Sampel.

\section{Hasil Dan Pembahasan}

Pada Penelitian Ini Penulis Mengumpulkan Data-Data Dengan Mengambil 60 Orang Atau Responden Untuk Dijadikan Sampel Dalam Menjawab Pernyataan-Pernyataan Yang Diajukan Penulis Mengenai Pengaruh Kualitas Produk Dan Harga Terhadap Minat Beli Konsumen Pada PT. Tiga Agung Dalam Bentuk Beberapa Pernyataan Atau Kuesioner Yang Diajukan Kepada 60 Orang Atau Responden.

Dalam Hal Ini Penulis Menganalisa Pengaruh Kualitas Produk Dan Harga Terhadap Minat Beli Dengan Menggunakan Penelitian Yang Dilakukan Dengan Cara Menyebar Kuisioner Kepada Responden. Penulis Membagikan Masing-Masing 10 Pernyataan Untuk Setiap Variabel Kepada 60 Orang Konsumen Yang Digunakan Sebagai Sampel. Berikut Ini Data Mengenai Profil Responden PT. Tiga Agung Dijelaskan Melalui Tabel Dibawah Ini.

\section{Hasil Penelitian Berdasarkan Responden}

\section{Jenis Kelamin}

Tabel 1. Data Berdasarkan Jenis Kelamin

\begin{tabular}{|ll|r|r|r|r|}
\hline & & & & & \\
& & Frequency & Percent & Valid Percent & Cumulative Percent \\
\hline Vali & Laki_Laki & 51 & 85,0 & 85,0 & 85,0 \\
\cline { 2 - 6 } d & Perempuan & 9 & 15,0 & 15,0 & 100,0 \\
\cline { 2 - 6 } & Total & 60 & 100,0 & 100,0 & \\
\hline
\end{tabular}

Sumber : Data Kuesioner Olahan SPSS 23

Berdasarkan Data Diatas Dapat Dilihat Bahwa Terdapat Jenis Kelamin Laki-Laki Dan Perempuan. Dimana Banyaknya Responden Yang Berjenis Kelamin Laki-Laki Sebanyak 51 Orang Dengan Persentase 85\% Sedangkan Responden Yang Berjenis Kelamin Perempuan Sebanyak 9 Orang Dengan Persentase 15\%. Dimana Jumlah Responden Terbanyak Adalah Responden Berjenis Kelamin Laki Laki Sebanyak 51 Orang Dengan Tingkat Persentase $85 \%$. 
eCo-Buss

\section{Usia}

Tabel 2. Data Responden Berdasarkan Usia

\begin{tabular}{|ll|r|r|r|r|}
\hline & & & & & \\
\hline & & Frequency & Percent & Valid Percent & Cumulative Percent \\
\hline Valid & $17-20$ th & 8 & 13,3 & 13,3 & 13,3 \\
\cline { 2 - 6 } & $21-25$ th & 48 & 80 & 80 & 80 \\
\cline { 2 - 6 } & 26-30th & 4 & 6,7 & 6,7 & 6,7 \\
\cline { 2 - 6 } & Total & 60 & 100,0 & 100,0 & \\
\hline
\end{tabular}

Sumber : Data Kuesioner Olahan SPSS 23

Berdasarkan Data Diatas Dilihat Bahwa Terdapat Tingkatan Usia. Dimana Tingkat Usia 17-20 Tahun Sebanyak 8 Orang Dengan Presentase 13,3\%, Tingkat Usia 21-25 Tahun Sebanyak 48 Orang Dengan Presentase 80\% Dan Tingkat Usia 26 - 30 Tahun Sebanyak 4 Orang Dengan Presentase 6,7\%. Dimana Tingkat Usia Terbanyak Adalah Dengan Tingkat Usia 21-25 Tahun Sebanyak 48 Orang Dengan Presentase 80\%.

\section{Pendidikan}

Tabel 3. Data Responden Berdasarkan Pendidikan

\begin{tabular}{|c|c|c|c|c|c|}
\hline & & Frequency & Percent & Valid Percent & Cumulative Percent \\
\hline \multirow{4}{*}{ Valid } & Sma & 5 & 8,3 & 8,3 & 8,3 \\
\hline & D1-D3 & 12 & 20,0 & 20,0 & 28,3 \\
\hline & $\mathrm{S} 1$ & 43 & 71,7 & 71,7 & 100,0 \\
\hline & Total & 60 & 100,0 & 100,0 & \\
\hline
\end{tabular}

Sumber: Data Kuesioner Olahan SPSS 23

Berdasarkan Data Diatas Dilihat Bahwa Terdapat Tingkatan Pendidikan. Dimana Tingkat SMA Sebanyak 5 Orang Dengan Presentase 8,3\%, Tingkat D1-D3 Sebanyak 12 Orang Dengan Presentase 20\%, Tingkat S1 Sebanyak 43 Orang Dengan Presentase 71,7\%. Dimana Tingkat Pendidikan Terbanyak Adalah Dengan Tingkat S1 Sebanyak 43 Orang Dengan Presentase 71,7\%.

\section{Pembahasan Penelitian}

\section{Uji Validitas Dan Reliabilitas Kualitas Produk (X1)}

Dalam Penelitian Ini Penulis Membuat 10 Pernyataan Yang Dinyatakan Untuk Variabel X1 Mengenai Kualitas Produk. Untuk Mengetahui Lebih Lanjut, Apakah Semua Pernyataan Tersebut Valid Dan Reliabel, Maka Dapat Dilakukan Uji Validitas Dan Reliabilitas.

\begin{tabular}{|ccc|}
\hline \multicolumn{2}{|c|}{ Tabel 4. Reliability Statistics } \\
Cronbach's Alpha & N Of Items \\
\hline &, 874 & \\
\hline
\end{tabular}

Sumber: Data Kuesioner Olahan SPSS 23

Pada Tabel 4 Reliability Statistics Diatas Dapat Dilihat Bahwa Nilai Cronbrach's Alpha Adalah Sebesar 0,874 Dengan Jumlah 10 Pernyataan. Jika Dibadingkan Dengan Nilai 
Alpha Romie Priyastama $(2017,170)$ Dalam Bukunya "Buku Sakti Kuasai SPSS Pengolahan Data \& Analisis Data", Maka Nilai Cronbrach's Alpha Dan Variabel Kualitas Produk Lebih Besar Dari Pada Nilai A = 0,60. Jadi Dapat Disimpulkan Bahwa Semua Kuesioner Tentang Kualitas Produk Tersebut Terbukti Dapat Diterima Dan Reliabel.

\begin{tabular}{|l|r|r|r|r|}
\hline & \multicolumn{5}{c}{ Tabel 5. Item-Total Statistics } & Corrected Item- \\
& $\begin{array}{c}\text { Scale Mean If } \\
\text { Item Deleted }\end{array}$ & $\begin{array}{c}\text { Scale Variance } \\
\text { If Item Deleted }\end{array}$ & $\begin{array}{c}\text { Conbach's Alpha If } \\
\text { Total Correlation } \\
\text { Item Deleted }\end{array}$ \\
\hline X1_1 & 33,2333 & 32,182 &, 395 &, 874 \\
\hline X1_2 & 33,3167 & 30,288 &, 595 &, 863 \\
\hline X1_3 & 33,4167 & 30,451 &, 554 &, 865 \\
\hline X1_4 & 33,4333 & 29,097 &, 639 &, 858 \\
\hline X1_5 & 33,5667 & 26,928 &, 778 &, 846 \\
\hline X1_6 & 33,7333 & 26,199 &, 790 &, 844 \\
\hline X1_7 & 33,7000 & 26,214 &, 786 &, 844 \\
\hline X1_8 & 33,4167 & 30,417 &, 314 &, 890 \\
\hline X1_9 & 33,4000 & 28,820 &, 577 &, 863 \\
\hline X1_10 & 33,2833 & 30,410 &, 623 &, 861 \\
\hline
\end{tabular}

Sumber : Data Kuesioner Olahan SPSS 23

Pada Tabel 5 Dapat Dijelaskan Bahwa:

a. Tabel Item-Total Statistic Menunjukan Hasil Perhitungan Validitas Untuk 10 Pernyataan.

b. Menentukan Besarnya Nilai $\mathrm{R}_{\text {tabel }}$ Dengan Ketentuan Tingkat Kepercayaan (Degree Of Freedom = Df) Jumlah Responden Dikurangi 2 Atau $60-2=58$ Dengan Tingkat Signifikan 5\% Maka $\mathrm{R}_{\text {tabel }}$ Sebesar 0,254.

c. Membandingkan $R_{\text {tabel }}$ Dengan Setiap Butir $R_{\text {hitung Pernyataan Dengan Cara }}$ Membandingkan Output Correlated Item Total Correlation Dengan 0,254 Rtabel.

d. Jika Dibandingkan Dengan $\mathrm{R}_{\text {tabel }}$ Pada Kolom Correlated Item Total Correlation. Nilai $R_{\text {hitung }}$ Semua Pernyataan Tentang Kualitas Produk Lebih Besar R table Artinya Semua Pernyataan Sudah Valid.

\section{Uji Validitas Dan Reliabilitas Harga (X2)}

Dalam Penelitian Ini Penulis Membuat 10 Pernyataan Yang Dinyatakan Untuk Variabel X2 Mengenai Harga. Untuk Mengetahui Lebih Lanjut, Apakah Semua Pernyataan Tersebut Valid Dan Reliabel, Maka Dapat Dilakukan Uji Validitas Dan Reliabilitas.

\begin{tabular}{|c|c|}
\hline \multicolumn{2}{|c|}{ Tabel 6. Reliability Statistics } \\
Cronbach's Alpha & N Of Items \\
\hline, 895 & \\
\hline
\end{tabular}

Sumber: Data Kuesioner Olahan SPPS 23

Pada Tabel 6 Reliability Statistics Diatas Dapat Dilihat Bahwa Nilai Cronbrach's Alpha Adalah Sebesar 0,895 Dengan Jumlah 10 Pernyataan. Jika Dibadingkan Dengan Nilai Alpha Romie Priyastama (2017, 170) Dalam Bukunya "Buku Sakti 
Kuasai SPSS Pengolahan Data \& Analisis Data", Maka Nilai Cronbrach's Alpha Dan Variabel Harga Lebih Besar Dari Pada Nilai A =0,60. Jadi Dapat Disimpulkan Bahwa Semua Kuesioner Tentang Harga Tersebut Terbukti Dapat Diterima Dan Reliabel.

\begin{tabular}{|c|c|c|c|c|}
\hline \multicolumn{5}{|c|}{ Tabel 7. Item-Total Statistics } \\
\hline & $\begin{array}{l}\text { Scale Mean If } \\
\text { Item Deleted }\end{array}$ & $\begin{array}{l}\text { Scale Variance } \\
\text { If Item Deleted }\end{array}$ & $\begin{array}{l}\text { Corrected Item- } \\
\text { Total Correlation }\end{array}$ & $\begin{array}{l}\text { Cronbach's Alpha If } \\
\text { Item Deleted }\end{array}$ \\
\hline $\mathrm{X} 2 \_1$ & 33,6667 & 23,989 &, 602 &, 887 \\
\hline $\mathrm{X} 2 \_2$ & 33,8833 & 23,969 & ,581 & ,888 \\
\hline $\mathrm{X} 2 \_3$ & 33,8500 & 24,231 &, 725 & ,882 \\
\hline $\mathrm{X} 2 \_4$ & 33,8833 & 22,918 & ,694 &, 880 \\
\hline$X 2 \_5$ & 34,1333 & 22,694 &, 578 &, 890 \\
\hline$X 2 \_6$ & 34,0667 & 23,114 & ,722 & ,879 \\
\hline $\mathrm{X} 2 \_7$ & 34,0667 & 22,843 & 640 &, 884 \\
\hline $\mathrm{X} 2 \_8$ & 34,0833 & 22,823 & ,601 & ,888 \\
\hline X2_9 & 34,0667 & 23,114 & 693 &, 881 \\
\hline$X 2 \_10$ & 33,9000 & 23,888 & 638 & 885 \\
\hline
\end{tabular}

Sumber : Data Kuesioner Olahan SPSS 23

Pada Tabel 7 Dapat Dijelaskan Bahwa :

a. Tabel Item-Total Statistic Menunjukan Hasil Perhitungan Validitas Untuk 10 Pernyataan.

b. Menentukan Besarnya Nilai $\mathrm{R}_{\text {tabel }}$ Dengan Ketentuan Tingkat Kepercayaan $($ Degree Of Freedom $=$ Df) Jumlah Responden Dikurangi 2 Atau $60-2=58$ Dengan Tingkat Signifikan 5\% Maka $\mathrm{R}_{\text {tabel }}$ Sebesar 0,254.

c. Membandingkan $R_{\text {tabel }}$ Dengan Setiap Butir $R_{\text {hitung Pernyataan Dengan Cara }}$ Membandingkan Output Correlated Item Total Correlation Dengan 0,254 Rtabel.

d. Jika Dibandingkan Dengan $\mathrm{R}_{\text {tabel }}$ Pada Kolom Correlated Item Total Correlation. Nilai $R_{\text {hitung }}$ Semua Pernyataan Tentang Harga Lebih Besar $R_{\text {table }}$ Artinya Semua Pernyataan Sudah Valid.

\section{Uji Vadilitas Dan Reliabilitas Variabel Minat Beli Konsumen (Y)}

Dalam Penelitian Ini Penulis Membuat 10 Pernyataan Yang Dinyatakan Untuk Variabel Y Tentang Minat Beli Konsumen. Untuk Mengetahui Lebih Lanjut, Apakah Semua Pernyatan Tersebut Reliable, Maka Dapat Dilakukan Uji Reabilitas Dengan Hasil Uji Reabilitas Sebagai Berikut:

\begin{tabular}{|c|c|}
\hline \multicolumn{2}{|c|}{ Tabel 8. Reliability Statistics } \\
\hline Cronbach's Alpha & $\mathrm{N}$ Of Items \\
\hline ,861 & 10 \\
\hline
\end{tabular}

Sumber : Data Kuesioner Olahan SPSS 23

Pada Tabel 8 Reliability Statistics Diatas Dapat Dilihat Bahwa Nilai Cronbrach's Alpha Adalah Sebesar 0,861 Dengan Jumlah 10 Pernyataan. Jika Dibandingkan Dengan Nilai Alpha Romie Priyastama (2017, 170) Dalam Bukunya "Buku Sakti 
Kuasai SPSS Pengolahan Data \& Analisis Data", Maka Nilai Cronbrach's Alpha Dan Variabel Minat Beli Lebih Besar Dari Pada Nilai A = 0,60. Jadi Dapat Disimpulkan Bahwa Semua Kuesioner Tentang Minat Beli Tersebut Terbukti Dapat Diterima Dan Reliabel.

\begin{tabular}{|lr|r|r|r|}
\hline & \multicolumn{5}{c}{ Tabel 9. Item-Total Statistics } & \\
& $\begin{array}{c}\text { Scale Mean If } \\
\text { Item Deleted }\end{array}$ & $\begin{array}{c}\text { Scale Variance } \\
\text { If Item Deleted }\end{array}$ & $\begin{array}{c}\text { Corrected Item- } \\
\text { Total Correlation }\end{array}$ & $\begin{array}{c}\text { Cronbach's Alpha } \\
\text { If Item Deleted }\end{array}$ \\
\hline Y_1 & 35,0833 & 18,790 &, 551 &, 850 \\
\hline Y_2 & 35,0167 & 18,695 &, 582 &, 848 \\
\hline Y_3 & 35,0500 & 18,116 &, 661 &, 842 \\
\hline Y_4 & 35,3000 & 18,044 &, 587 &, 847 \\
\hline Y_5 & 35,2167 & 17,732 &, 547 &, 851 \\
\hline Y_6 & 35,3500 & 18,164 &, 567 &, 849 \\
\hline Y_7 & 35,5000 & 17,475 &, 539 &, 853 \\
\hline Y_8 & 35,1000 & 17,617 &, 619 &, 844 \\
\hline Y_9 & 35,1333 & 19,202 &, 478 &, 855 \\
\hline Y_10 & 35,4500 & 16,964 &, 630 &, 843 \\
\hline
\end{tabular}

Sumber : Data Kuesioner Olahan SPSS 23

Pada Tabel 9 Dapat Dijelaskan Bahwa :

a. Tabel Item-Total Statistic Menunjukan Hasil Perhitungan Validitas Untuk 10 Pernyataan.

b. Menentukan Besarnya Nilai $\mathrm{R}_{\text {tabel }}$ Dengan Ketentuan Tingkat Kepercayaan (Degree Of Freedom $=$ Df) Jumlah Responden Dikurangi 2 Atau $60-2=58$ Dengan Tingkat Signifikan 5\% Maka $\mathrm{R}_{\text {tabel }}$ Sebesar 0,254.

c. Membandingkan $\mathrm{R}_{\text {tabel }}$ Dengan Setiap Butir $\mathrm{R}_{\text {hitung }}$ Pernyataan Dengan Cara Membandingkan Output Correlated Item Total Correlation Dengan 0,254 $\mathrm{R}_{\text {tabel. }}$

d. Jika Dibandingkan Dengan $\mathrm{R}_{\text {tabel }}$ Pada Kolom Correlated Item Total Correlation. Nilai R Ritung Semua Pernyataan Tentang Minat Beli Lebih Besar $R_{\text {table }}$ Artinya Semua Pernyataan Sudah Valid.

\section{Hasil Analisa Penelitian}

1. Pengaruh Kualitas Produk Dan Harga Terhadap Minat Beli Konsumen Smartphone Bergaransi Distributor Pada PT. Tiga Agung

Dalam Penelitian Ini, Penulis Menggunakan Populasi Sebanyak 60 Responden. Penulis Menganalisis Pengaruh Kualitas Produk Dan Harga Terhadap Minat Beli Konsumen Smartphone Bergaransi Distributor Pada PT. Tiga Agung Dengan Menggunakan Penelitian. Penelitian Dilakukan Dengan Pembagian Kuesioner, Penulis Memberikan 10 Pernyataan Dari Setiap Indikatornya Mengenai Kualitas Produk, 10 Pernyataan Mengenai Harga, Dan 10 Pernyataan Mengenai Minat Beli Konsumen Terhadap 60 Orang Konsumen Yang Digunakan Sebagai Sampel.

Untuk Mengetahui Ada Atau Tidaknya Pengaruh Antara Variabel X1 ( Kualitas Produk ) Dan Variabel X2 ( Harga ) Dengan Variabel Y ( Minat Beli Konsumen ) Serta Mengukur Kuat Tidaknya Pengaruh Tersebut, Maka Digunakan Analisa Regresi Liniear 
eCo-Buss

Berganda Dengan Menggunakan Perhitungan SPSS (Statistical Package For Service Softition), Berikut Ini Hasil Analisis Regresi Liniear Berganda Adalah Sebagai Berikut :

Tabel 10. Hasil Perhitungan Standar Deviasi

\begin{tabular}{|lr|r|r|}
\hline \multicolumn{4}{|c|}{ Descriptive Statistics } \\
& Mean & Std. Deviation & N \\
\hline Minat_Beli & 39,1333 & 4,68849 & 60 \\
\hline Kualitas_Produk & 36,9000 & 5,72150 & 60 \\
\hline Harga & 37,7333 & 5,33891 & 60 \\
\hline
\end{tabular}

Sumber : Data Kuesioner Olahan SPSS 23

Pada Tabel 10 Dapat Dilihat Bahwa:

a. Mean (Rata-Rata) Dari Variabel Y (Minat Beli Konsumen) Dengan Jumlah Responden 60 Orang Adalah 39,13 Dengan Standar Devisiasi Sebesar 4,68849.

b. Mean (Rata-Rata) Dari Variabel X1(Kualitas Produk) Dengan Jumlah Responden 60 Orang Adalah 36,90 Dengan Standar Devisiasi Sebesar 5,72150.

c. Mean (Rata-Rata) Dari Variabel X2 (Harga) Dengan Jumlah Responden 60 Orang Adalah 37,73 Dengan Standar Devisiasi Sebesar 5,33891.

Tabel 11. Tabel Perhitungan Koefisien Korelasi

\begin{tabular}{|c|c|c|c|c|}
\hline \multicolumn{5}{|c|}{ Correlations } \\
\hline & & Minat_Beli & Kualitas_Produk & Harga \\
\hline \multirow[t]{3}{*}{ Pearson Correlation } & Minat_Beli & 1,000 & ,694 & 629 \\
\hline & $\begin{array}{l}\text { Kualitas_Produ } \\
\text { k }\end{array}$ & ,694 & 1,000 & 679 \\
\hline & Harga & ,629 & 679 & 1,000 \\
\hline \multirow[t]{3}{*}{ Sig. (1-Tailed) } & Minat_Beli & & ,000 & ,000 \\
\hline & $\begin{array}{l}\text { Kualitas_Produ } \\
\mathrm{k}\end{array}$ & ,000 & & 000 \\
\hline & Harga &, 000 & ,000 & \\
\hline \multirow[t]{3}{*}{$\mathrm{N}$} & Minat_Beli & 60 & 60 & 60 \\
\hline & $\begin{array}{l}\text { Kualitas_Produ } \\
\text { k }\end{array}$ & 60 & 60 & 60 \\
\hline & Harga & 60 & 60 & 60 \\
\hline
\end{tabular}

Sumber : Data Kuesioner SPSS 23

Dari Tabel Diatas Dapat Dilihat Bahwa :

a. Besar Hubungan Pengaruh Kualitas Produk Terhadap Minat Beli Konsumen Smartphone Bergaransi Distributor Pada PT. Tiga Agung Yang Ditunjukan Dengan Nilai Keofiesien Korelasi Sebesar 0,694 Mendekati 1, Yang Artinya Korelasi Cukup Kuat Dan Memiliki Arah Yang Positif. 
b. Besar Hubungan Pengaruh Harga Terhadap Minat Beli Konsumen Smartphone Bergaransi Distributor Pada PT. Tiga Agung Ditunjukkan Dengan Nilai Koefisien Korelasi Sebesar 0,629 Mendekati 1, Yang Artinya Korelasi Cukup Kuat Dan Memiliki Arah Yang Positif.

Tabel Correlations Menunjukan Bahwa:

Pengaruh Kualitas Produk Dan Harga Dapat Dilihat Dari Angka Probabilitas Sebesar $0,000<0,05$ Dimana Jika Angka Probabilitas < 0,05, Maka Terdapat Hubungan Yang Signifikan Antara Ketiga Variabel Tersebut. Dapat Dilihat Dari Tabel Diatas, Nilai Probabilitas Pada Kolom Signifikan Sebesar 0,000 Menunjukan Korelasi Ketiga Variabel Adalah Signifikan Yang Artinya Menolak Ho Dan Menerima Ha.

Tabel 12. Tabel Metode Stepwise

\begin{tabular}{|c|c|c|c|}
\hline \multicolumn{4}{|c|}{ Variables Entered/Removed ${ }^{\mathbf{a}}$} \\
\hline Model & $\begin{array}{l}\text { Variables } \\
\text { Entered }\end{array}$ & $\begin{array}{l}\text { Variables } \\
\text { Removed }\end{array}$ & Method \\
\hline 1 & $\begin{array}{l}\text { Kualitas_Produ } \\
\mathrm{k}\end{array}$ & & $\begin{array}{l}\text { Stepwise (Criteria: } \\
\text { Probability-Of-F-To- } \\
\text { Enter }<=, 050, \\
\text { Probability-Of-F-To- } \\
\text { Remove }>=, 100) \text {. }\end{array}$ \\
\hline 2 & Harga & & $\begin{array}{l}\text { Stepwise (Criteria: } \\
\text { Probability-Of-F-To- } \\
\text { Enter }<=, 050, \\
\text { Probability-Of-F-To- } \\
\text { Remove }>=, 100) \text {. }\end{array}$ \\
\hline A. D & dent Variable & t_Beli & \\
\hline
\end{tabular}

Dari Tabel Diatas Dapat Dilihat Kualitas Produk Dan Harga Merupakan Variabel Masukan (Variabel Entered), Karena Probabilitas Dari Kualitas Produk Dan Harga Memenuhi Kriteria Probabilitas. Dimana Probabilitas Dari Kualitas Produk Dan Harga Dibawah 0,05.

Tabel 13. Tabel Hasil Perhitungan Koefisien Determinasi

\begin{tabular}{|c|c|c|c|c|c|c|c|c|c|}
\hline \multicolumn{10}{|c|}{ Model Summary } \\
\hline \multirow[b]{2}{*}{ Model } & \multirow[b]{2}{*}{$\mathrm{R}$} & \multirow[b]{2}{*}{$\begin{array}{c}\mathrm{R} \\
\text { Square }\end{array}$} & \multirow[b]{2}{*}{$\begin{array}{l}\text { Adjust } \\
\text { ed R } \\
\text { Square }\end{array}$} & \multirow[b]{2}{*}{$\begin{array}{l}\text { Std. Error } \\
\text { Of The } \\
\text { Estimate }\end{array}$} & \multicolumn{5}{|c|}{ Change Statistics } \\
\hline & & & & & $\begin{array}{c}\text { R } \\
\text { Square } \\
\text { Change }\end{array}$ & $\begin{array}{c}\mathrm{F} \\
\text { Change }\end{array}$ & Df1 & Df2 & $\begin{array}{c}\text { Sig. F } \\
\text { Change }\end{array}$ \\
\hline 1 &, $694^{\mathrm{a}}$ & ,481 & 472 & 3,40625 & 481 & 53,780 & 1 & 58 &, 000 \\
\hline 2 &, $726^{\mathrm{b}}$ &, 528 &, 511 & 3,27856 & ,046 & 5,606 & 1 & 57 & 021 \\
\hline
\end{tabular}

A. Predictors: (Constant), Kualitas_Produk

B. Predictors: (Constant), Kualitas_Produk, Harga

C. Dependent Variable: Minat_Beli

Sumber : Hasil Pengolahan Data SPSS 23 
Dari Tabel Diatas Dapat Dilihat Dilihat Bahwa :

a. Kolom R Model 1 Menunjukan Bahwa Angka Koefisien Korelasi Yaitu Sebesar 0,694. Hal Ini Berarti Adanya Pengaruh Antara Kualitas Produk Terhadap Minat Beli Konsumen Kuat.

b. Kolom R Square Untuk Model 1 Menunjukan Angka R Square Adalah 0,481 (Adalah Pengkuadratan Dari Koefisien Korelasi Atau 0,694 X 0,694 = 0,481). R Square Disebut Juga Koefisien Determinasi. Hal Ini Berarti Besarnya Pengaruh Kualitas Produk Terhadap Minat Beli Konsumen Adalah (48,1\%) Sedangkan Sisanya $(100 \%-48,1 \%=51,9 \%)$ Di Pengaruhi Faktor-Faktor Lain. R Square Berkisar 0 Sampai 1, Semakin Kecil Angka R Square Menunjukan Semakin Kuat Hubungan Antara Variabel Dan Sebaliknya.

c. Kolom Adjusted $R$ Square Untuk Model 1 Adalah Sebesar 0,472

d. Kolom Standar Error Of Th Estimate Untuk Model 1 Adalah Sebesar 3.40625.

e. Perhatikan Pada Tabel 4.43 Diatas Bahwa Nilai Standar Deviasi Minat Beli Konsumen Adalah 4.68849 Yang Jauh Lebih Besar Dari Std. Error Of The Estimate Yang Hanya Sebesar 3.40625.

f. Kolom R Untuk Model 2 Menunjukkan Angka Koefisien Korelasi Yaitu Sebesar 0,726. Hal Ini Berarti Hubungan Antara Kualitas Produk Dan Harga Terhadap Minat Beli Adalah Cukup Kuat.

g. Kolom R Square Untuk Model 2 Menunjukkan Angka R Square Sebesar 0,528 (Adalah Pembulatan Serta Pengkuadratan Dari Koefisien Korelasi Atau 0,726 X 0,726 = 0,528). R Square Disebut Juga Koefisien Determinasi. Hal Ini Berarti Besarnya Pengaruh Kualitas Produk Dan Harga Terhadap Minat Beli Konsumen Adalah 52,8\%, Sedangkan Sisanya $(100 \%$ - 52,8\% = 47,2\%) Dipengaruhi Oleh Faktor-Faktor Lain Berkisar Pada 0 Sampai 1, Semakin Kecil R Square Menunjukan Semakin Lemah Pengaruh Antara Variabel Dan Sebaliknya.

h. Kolom Adjusted R Square Untuk Model 2 Adalah Sebesar 0,511.

i. Kolom Std. Error Of The Estimate Untuk Model 2 Adalah Sebesar 3.27856.

j. Perhatikan Pada Tabel 4.43 Di Atas Bahwa Nilai Standar Deviasiasi Minat Beli Konsumen Adalah Sebesar 4.68849 Yang Jauh Lebih Besar Dari Std. Error Of The Estimate Yang Hanya Sebesar 3.27856.

Tabel 14. Hasil Perhitungan Anova

\begin{tabular}{|c|c|c|c|c|c|c|}
\hline \multicolumn{7}{|c|}{ Anova $^{a}$} \\
\hline \multicolumn{2}{|c|}{ Model } & $\begin{array}{l}\text { Sum Of } \\
\text { Squares }\end{array}$ & Df & $\begin{array}{l}\text { Mean } \\
\text { Square }\end{array}$ & $\mathrm{F}$ & Sig. \\
\hline \multirow[t]{3}{*}{1} & Regression & 623,985 & 1 & 623,985 & 53,780 &, $000^{\mathrm{b}}$ \\
\hline & Residual & 672,948 & 58 & 11,603 & & \\
\hline & Total & 1296,933 & 59 & & & \\
\hline \multirow[t]{3}{*}{2} & Regression & 684,244 & 2 & 342,122 & 31,828 &, $000^{c}$ \\
\hline & Residual & 612,689 & 57 & 10,749 & & \\
\hline & Total & 1296,933 & 59 & & & \\
\hline
\end{tabular}

A. Dependent Variable: Minat_Beli

B. Predictors: (Constant), Kualitas_Produk

C. Predictors: (Constant), Kualitas_Produk, Harga 
Sumber : Hasil Pengolahan Data SPSS 23

Dari Tabel Diatas Dapat Dilihat Dilihat Bahwa :

a. Dari Uji ANOVA Didapat $F_{\text {hitung }}$ Untuk Model 1 Adalah 53,780 Dengan Tingkat Signifikan 0,000 Dimana Angka 0,000 < 0,05 Dan Juga $F_{\text {hitung }}>F_{\text {tabel }}$ Atau 53,780 > 3,16, Dengan Demikian Ho Ditolak Dan Ha Diterima Artinya Terdapat Pengaruh Antara Variabel Kualitas Produk (X1) Dan Harga (X2) Dengan Minat Beli Konsumen, Maka Model Regresi Tersebut Sudah Layak Dan Tepat.

b. Dari Uji ANOVA Didapat $F_{\text {hitung }}$ Untuk Model 2 Adalah 31,828 Dengan Tingkat Signifikan 0,000 Dimana Angka 0,000 <0,05 Dan Juga $F_{\text {hitung }}>F_{\text {tabel }}$ Atau 31,828 > 3,16, Dengan Demikian Ho Ditolak Dan Ha Diterima Artinya Terdapat Pengaruh Antara Variabel Kualitas Produk (X1) Dan Harga (X2) Minat Beli Konsumen, Maka Model Regresi Tersebut Sudah Layak Dan Tepat.

\begin{tabular}{|c|c|c|c|c|c|c|}
\hline \multicolumn{7}{|c|}{ Tabel 15. Coefficients ${ }^{\mathrm{a}}$} \\
\hline \multirow{2}{*}{\multicolumn{2}{|c|}{ Model }} & \multicolumn{2}{|c|}{$\begin{array}{l}\text { Unstandardized } \\
\text { Coefficients }\end{array}$} & \multirow{2}{*}{$\begin{array}{c}\text { Standardized } \\
\text { Coefficients } \\
\text { Beta } \\
\end{array}$} & \multirow[b]{2}{*}{$\mathrm{T}$} & \multirow[b]{2}{*}{ Sig. } \\
\hline & & $\mathrm{B}$ & Std. Error & & & \\
\hline \multirow[t]{2}{*}{1} & (Constant) & 18,160 & 2,894 & & 6,276 & ,000 \\
\hline & $\begin{array}{l}\text { Kualitas_Produ } \\
\text { k }\end{array}$ & ,568 & ,078 & ,694 & 7,333 &, 000 \\
\hline \multirow[t]{3}{*}{2} & (Constant) & 14,458 & 3,194 & & 4,527 &, 000 \\
\hline & $\begin{array}{l}\text { Kualitas_Produ } \\
\text { k }\end{array}$ & ,405 & , 102 & ,494 & 3,988 & 000 \\
\hline & Harga & ,258 & ,109 & ,294 & 2,368 & 021 \\
\hline
\end{tabular}

Sumber : Hasil Pengolahan Data SPSS 23

Dari Tabel Diatas Dapat Dilihat Dilihat Bahwa :

a. Untuk Penyusunan Persamaan Regresi Dari Data Diatas, Dapat Menggunakan NilaiNilai Dari B Yaitu Unstandardized Coefficients. Dari Kolom B Ini Didapat Nilai Konstan Sebesar 14,458, Sedangkan Untuk Nilai Koefisien Variabel Kualitas Produk (X1) Sebesar 0.405 Dan Variabel Harga Harga (X2) Sebesar 0.258.

b. Dari Nilai-Nilai Koefisien Diatas Persamaan Regresi Sebagai Berikut :

$\mathrm{Y}=\mathrm{A}+\mathrm{B} 1 \mathrm{x} 1+\mathrm{B} 2 \mathrm{x} 2$

$\mathrm{Y} \quad=$ Minat Beli Konsumen

$\mathrm{X}_{1}=$ Kualitas Produk.

$\mathrm{X}_{2} \quad$ = Harga.

$\alpha=$ Konstanta.

$\mathrm{B}_{1} \quad=$ Koefisien Regresi Kualitas Produk.

$\mathrm{B}_{2}=$ Koefisien Regresi Harga.

Maka Diperoleh Persamaan, $\mathrm{Y}=14,458+0.405 \mathrm{X}_{1}+0.258 \mathrm{X}_{2}$ 
c. Pada Saat Variabel X1 (Kualitas Produk) Terjadi Peningkatan Atau Penurunan Sebesar 1 Poin Maka Variabel Y (Minat Beli Konsumen) Akan Mengalami Peningkatan Atau Penurunan Sebesar 0,405.

d. Pada Saat Variabel X2 (Harga) Terjadi Peningkatan Atau Penurunan Sebesar 1 Poin Maka Variabel Y (Minat Beli Konsumen) Akan Mengalami Peningkatan Atau Penurunan Sebesar 0,258.

e. Untuk Regresi Berganda, Angka Korelasi Pengaruh Kualitas Produk (X1) Sebesar 0, 494 Dan Angka Korelasi Harga (X2) Sebesar 0,294 Adalah Hasil Yang Didapat Pada Kolom Standardized Coefficient (Beta).

f. Pada Kolom T Digunakan Pengujian T Untuk Menguji Kebenaran Dari Hipotesis Yang Ada, Dilakukan Dengan Cara Membandingkan Nilai $T_{\text {hitung }}$ Yang Diperoleh Dengan Nilai Tabel

Kriteria Pengujian :

1) Jika $T_{\text {hitung }}>T_{\text {tabel }}$ Maka Ho Ditolak Dan Ha Diterima.

2) Jika $T_{\text {hitung }}<T_{\text {tabel }}$ Maka Ho Diterima Dan Ha Ditolak.

3) Pada Kolom $T$ Diketahui Bahwa $T_{\text {hitung }}$ Untuk Kualitas Produk (X1) Adalah Sebesar 3.988 Dengan Menggunakan Tabel Distribusi Normal $T$ Dan Menggunakan Tingkat Keyakinan Pengujian ( 1 - A ) Sebesar 95\% Dan Tingkat Kesalahan (A) N-2 = 60 $-2=58$, Maka Diperoleh Nilai Distribusi Tabel $\mathrm{T}$ Adalah 2.001. Oleh Karena $\mathrm{T}_{\text {hitung }}$ Kualitas Produk Lebih Besar Dari $\mathrm{T}_{\text {tabel }}$ Atau 3,988 > 2.001, Maka Ho Ditolak Dan Ha Diterima.

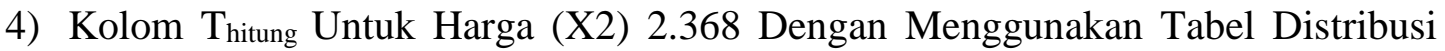
Normal T Dan Menggunakan Tingkat Kesalahan (A) Sebesar 95\% Dan Tingkat Kesalahan (Df) N-2 =60 $-2=58$, Maka Diperoleh Nilai Distribusi Tabel T Adalah 2.001. Oleh Karena Itu $T_{\text {hitung }}$ Harga Lebih Besar Dari Tabel T Atau 2.368 > 2.001, Maka Ho Ditolak Dan Ha Diterima.

g. Pada Kolom Signifikan Digunakan Untuk Pengujian Probabilitas. Kriteria Pengujian: Jika Probabilitas < 0,05 Maka Ho Ditolak Dan Ha Diterima. Jika Probabilitas > 0,05 Maka Ho Diterima Dan Ha Ditolak.

h. Terlihat Pada Kolom Signifikan Diketahui Nilai Probilitas Untuk Kualitas Produk (Variabel X1) Adalah 0,000 Dan Harga (Variabel X2) Adalah 0.021 Atau Nilai Probabilitas Jauh Di Bawah 0,05, Dengan Demikian Maka Ho Ditolak Dan Ha Diterima, Dengan Kata Lain Koefisien Regresi Signifikan, Artinya Kualitas Produk (Variabel X1) Dan Harga (Variabel X2) Benar-Benar Sangat Berpengaruh Terhadap Minat Beli Konsumen (Variabel Y).

\section{Kesimpulan}

Berdasarkan Hasil Penelitian, Diperoleh Kesimpulan Bahwa Kualitas Produk Dan Harga Berpengaruh Terhadap Minat Beli Konsumen Smartphone Bergaransi Distributor Pada PT. Tiga Agung, Berikut Ini Adalah Kesimpulan Dari Hasil Penelitian :

1. Analisa Variabel Kualitas Produk Terhadap Minat Beli Konsumen Adalah Besar Pengaruh Kualitas Produk Ditunjukan Dengan Nilai Koefisien Korelasi Sebesar 0,694 Mendekati 1, Dimana Korelasi Memiliki Hubungan Yang Positif Dan Kuat. Dari Hasil Pengujian $\mathrm{T}$ Memperoleh $\mathrm{T}_{\text {hitung }}>\mathrm{T}_{\text {tabel }}(3.988>2.001$ ) Dan Memiliki Signifkasi Sebesar 0,00 Nilai Ini Lebih Kecil Dari 0,00 ( 0,000 > 0,05 ). Ini Berarti Ho Ditolak Dan 
Ha Diterima. Sehingga Dapat Disimpulkan Bahwa Kualitas Produk Berpengaruh Positif Dan Signifikan Terhadap Minat Beli Konsumen.

2. Analisa Variabel Harga Terhadap Minat Beli Konsumen Adalah Besar Pengaruh Harga Ditunjukan Dengan Nilai Koefisien Korelasi Sebesar 0,629 Mendekati 1, Dimana Korelasi Memiliki Hubungan Yang Positif Dan Kuat. Dari Hasil Pengujian $T$ Memperoleh $\mathrm{T}_{\text {hitung }}>\mathrm{T}_{\text {tabel }}(2.368>2.001)$ Dan Memiliki Signifkasi Sebesar 0.00 Nilai Ini Lebih Kecil Dari 0,00 ( 0,000 > 0,05 ). Ini Berarti Ho Ditolak Dan Ha Diterima. Sehingga Dapat Disimpulkan Bahwa Harga Berpengaruh Positif Dan Signifikan Terhadap Minat Beli Konsumen.

3. Analisa Variabel Kualitas Produk Dan Harga Terhadap Minat Beli Konsumen Adalah Terdapat Pengaruh Yang Kuat Antara Kualitas Produk Dan Harga Terhadap Minat Beli Konsumen. Dari Hasil Pengujian F Memperoleh Nilai Didapat $F_{\text {hitung }}>F_{\text {tabel }}$ Atau (53.780 $>$ 3,16), Nilai Ini Lebih Kecil Dari 0,05 $(0,000<0,05)$, Dengan Demikian Ho Ditolak Dan Ha Diterima Artinya Terdapat Pengaruh Linear Antara Variabel Kualitas Produk Dengan Minat Beli Konsumen. Sedangkan Dari Hasil Pengujian F Memperoleh Nilai Didapat $F_{\text {hitung }}>F_{\text {tabel }}(31.828>3,16)$, Nilai Ini Lebih Kecil 0,05 $(0,000<0,05)$, Dengan Demikian Ho Ditolak Dan Ha Diterima Artinya Terdapat Pengaruh Linear Antara Variabel Harga Dengan Minat Beli Konsumen. Sehingga Dapat Disimpulkan Bahwa Kualitas Produk Dan Harga Berpengaruh Positif Dan Signifikan Terhadap Minat Beli Konsumen.

\section{Daftar Pustaka}

Andy, A. (2018). FAKTOR YANG MEMPENGARUHI KEPUTUSAN PEMBELIAN KONSUMEN GERAI ALFAMIDI TAMAN ROYAL TANGERANG. Primanomics, $1-8$.

Annafik, F. A., \& Rahardjo, M. (2012). ANALISIS PENGARUH KUALITAS PRODUK, HARGA, DAN DAYA TARIK IKLAN TERHADAP MINAT BELI SEPEDA MOTOR YAMAHA (Studi Kasus Pada Konsumen Yamaha SS Cabang Kedungmundu Semarang). Diponegoro Journal Of Management, 274-281.

Bachriansyah, A. R. (2011). Analisis Pengaruh Kualitas Produk, Daya Tarik Iklan, Dan Persepsi Harga Terhadap Minat Beli Konsumen Pada Produk Ponsel Nokia (Studi Kasus Pada Masyarakat Di Kota Semarang). Semarang: Universitas Diponegoro.

Buchari, A. (2011). Manajemen Pemasaran Dan Pemasaran Jasa. Bandung: Alfabeta.

Sugiyono. (2010). Pendekatan Kuantitatif, Kualitatif, Dan R\&B. Bandung: Alpabeta.

Yasa, N. K., \& Prawira, B. (2014). Pengaruh Kualitas Produk, Citra Merek Dan Persepsi Harga Terhadap Minat Beli Produk Smartphone Samsung Di Kota Denpasar. EJurnal Manajemen, 3642. 